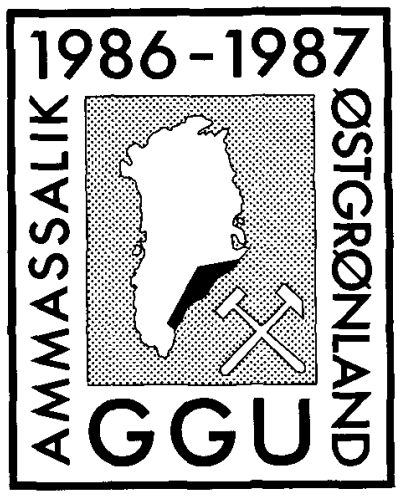

\title{
The southern boundary zone of the Proterozoic mobile belt, South-East Greenland: geology of the area between Gyldenløve Fjord and Isertoq
}

\author{
J. C. Escher, C. R. L. Friend and R. P. Hall
}

\begin{abstract}
The Gyldenløve Fjord - Isertoq region consists mainly of grey amphibolite facies gneisses with rare units of supracrustal rocks. The region is cut by a dense swarm of E-W trending basic dykes which are presumed to be of Proterozoic age. The dykes clearly predate the Proterozoic deformation of the northern and central parts of the region, which represents the southern part of the Proterozoic mobile belt of SouthEast Greenland. The gneisses south of the mobile belt in the southern part of the region are presumed to be Archaean and are cut by undeformed dykes. The gneisses and dykes within the mobile belt, in contrast, have been strongly sheared and folded but contain occasional tectonic augen of nebulitic gneiss with variably preserved Archaean structures. The southern boundary of the mobile belt bordering the unmodified Archaean gneisses consists of an approximately $25 \mathrm{~km}$ wide zone of gradually declining deformation and is in many respects comparable to the northern boundary of the mobile belt, described elsewhere in this volume.
\end{abstract}

\section{Introduction}

The coastal section of the gneiss complex in the region between Gyldenløve Fjord and Isertoq $\left(64^{\circ}\right.$ to $65^{\circ} 30^{\prime} \mathrm{N}$; fig. 1) has been described by Bridgwater \& Gormsen (1968, 1969), Bridgwater \& Myers (1979) and Myers $(1984,1987)$ as comprising two structurally different areas. The area between Isertoq and southern Jens Munk $\emptyset$ (further referred to as 'the northern area') was considered to belong to the Nagssugtoqidian mobile belt of East Greenland, and Nag. 1 and Nag. 2 events were distinguished. This was based on the assumption that the chronology established for the Nagssugtoqidian mobile belt of West Greenland could be directly correlated with events in South-East Greenland. This correlation, however, is now considered as uncertain (Chadwick et al., this volume). The area between southern Jens Munk $\emptyset$ and Gyldenløve Fjord (further referred to as 'the southern area') was considered by Bridgwater \& Gormsen $(1968,1969)$ and Bridgwater \& Myers (1979) as part of the Archaean craton of South-East Greenland, and unaffected by Proterozoic deformation. The boundary between the two areas was depicted as a line of abrupt transition from intensely sheared rocks to undeformed rocks at the southern end of Jens Munk $\emptyset$ (Bridgwater \& Myers, 1979, fig. 1; Myers, 1987, fig. 2).

The gneiss complex between Gyldenløve Fjord and Isertoq was re-investigated by us in the summer of 1986 , during nine days of intensive helicopter reconnaissance mapping (fig. 1). Our investigation confirms the main findings of Bridgwater \& Gormsen $(1968,1969)$ and Bridgwater \& Myers (1979), but it also revealed important differences from the previous descriptions, interpretations and maps, particularly with respect to the location of the southern boundary of the mobile belt and the Nagssugtoqidian interpretation model of the deformational events inside the belt.

The Gyldenløve Fjord - Isertoq region consists mainly of grey amphibolite facies gneisses with rare units of supracrustal rocks. The entire region is cut by a dense swarm of predominantly $\mathrm{E}-\mathrm{W}$ trending basic dykes which are presumed to be Proterozoic. They clearly pre-date most of the Proterozoic deformation of the mobile belt. The gneisses of the southern area are unmodified and presumed to be Archaean with undeformed E-W trending basic dykes. In contrast, the gneisses and basic dykes in the northern area have been strongly sheared and folded during the Proterozoic. The boundary between the two areas is formed by a $25 \mathrm{~km}$ wide zone of gradual increase in deformation.

\section{Supracrustal rocks}

Supracrustal rocks are notably uncommon in the Gyldenløve Fjord - Isertoq region in contrast with the 


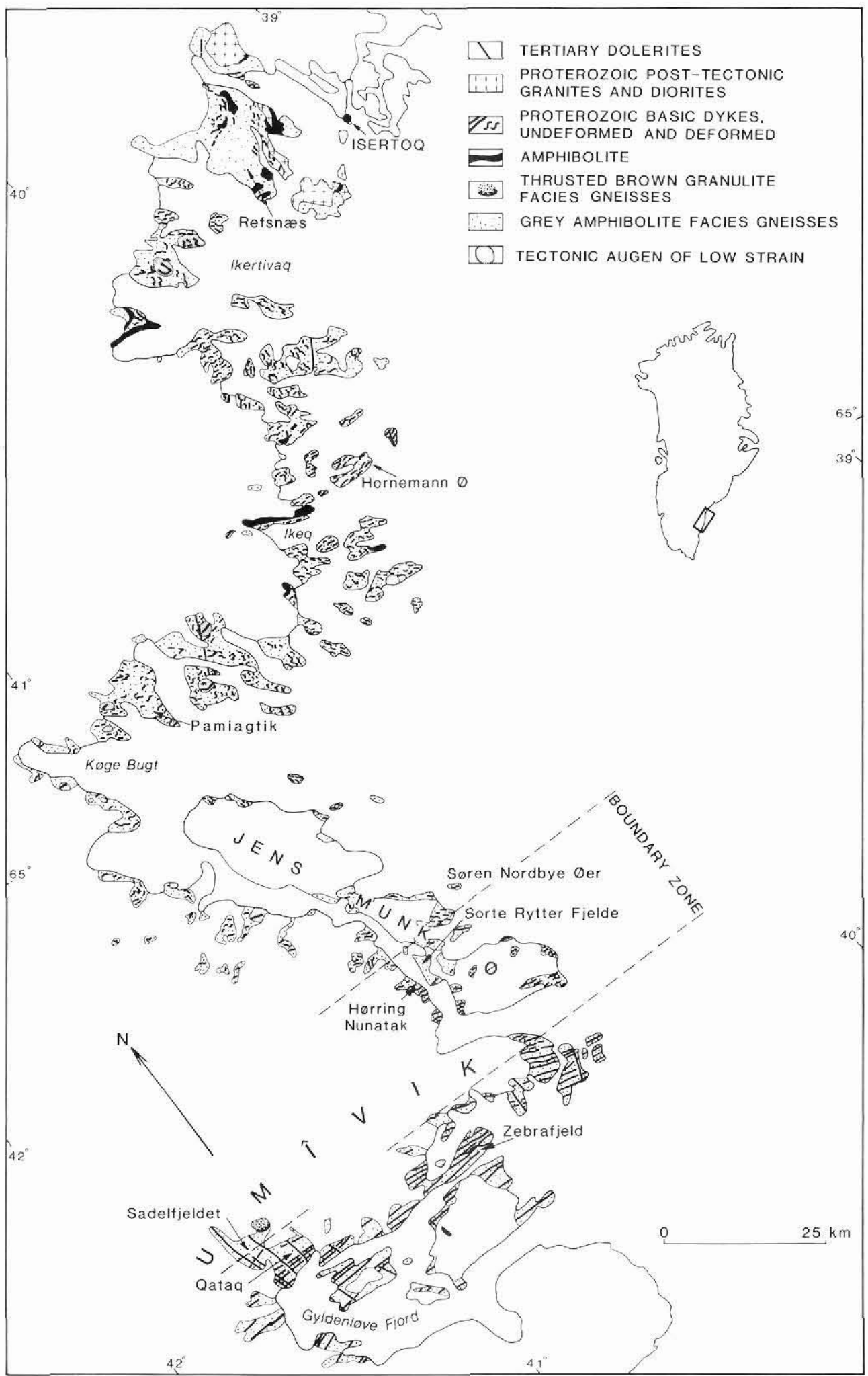

Fig. 1. Simplified geological map of the region between Isertoq and Umivik, including the southern boundary zone of the Proterozoic mobile belt. Geology based on reconnaissance mapping during 1986. 


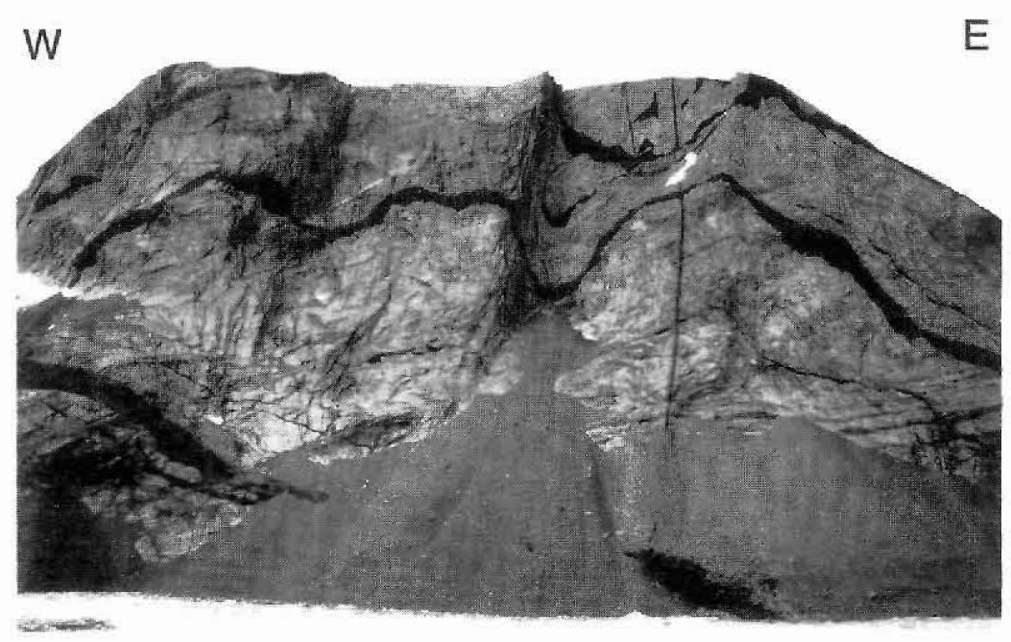

E Fig. 2. Archaean gneiss complex south of the Proterozoic mobile belt showing two major dyke emplacement directions. E-W dykes are Proterozoic, the $\mathrm{N}-\mathrm{S}$ dykes are presumed to be Tertiary and have reddened and altered gneisses along their margins. Qataq, western Gyldenløve Fjord, cliff face $1355 \mathrm{~m}$ high.

region around Ammassalik to the north where they are abundant (Chadwick et al., this volume; Hall et al., this volume - Supracrustals). In fact, the only significant supracrustal rocks comprise folded units of striped amphibolites west and north of Ikertivaq and an identical unit north of Ikeq (fig. 1). A few kyanite-bearing metasedimentary enclaves occur in trains in the gneisses north of Køge Bugt.

\section{Archaean gneiss complex}

Unmodified Archaean gneisses occur south of the mobile belt around Gyldenløve Fjord where they mainly comprise a mixture of grey, pegmatite-banded to nebulitic, quartzo-feldspathic rocks. In general, these rocks show clear indications of a complex tectonometamorphic history prior to the emplacement of the E-W basic dykes. Most of the gneisses preserve amphibolite facies mineralogies. However, in many places, particularly where the gneisses are nebulitic, they have a bleached appearence or a faint purplish colour reminiscent of retrogressed granulite facies gneisses, although no altered orthopyroxene could be identified in these rocks in the field.

In several places the gneisses contain diffuse inclusions, often associated with the development of epidote. Mappable zones of enclaves within the gneisses are rare and they are restricted to basic lithologies. Mixed metagabbro, leucogabbro and anorthosite enclaves, presumably derived from a dismembered layered intrusion, occur at several locations. The enclaves, which are most often in the order of a metre long, are frequently very coarse grained and closely resemble the deformed 'tennis ball' leucogabbros of the Fiskenæsset anorthosite complex in southern West Greenland (Myers, 1985). During the disruption and fragmentation of these en- claves, many individual feldspar crystals have become separated from their matrix and now occur as discrete xenocrysts within the quartzo-feldspathic gneiss. Using these xenocrysts as strain markers, it is clear that the Archaean deformation was inhomogeneous, such that the enveloping host gneisses are highly deformed whilst the enclaves and xenocrysts show very variable, but commonly lower, strain states.

\section{Undeformed Proterozoic dykes}

The Archaean gneisses south of the Proterozoic mobile belt contain two major sets of basic dykes, characterised by their orientations (figs 1,2 ). A clearly younger set of relatively few, roughly $\mathrm{N}-\mathrm{S}$ trending dykes (probably of Tertiary age, see below) cross cuts abundant, assumed Proterozoic, basic dykes trending $70^{\circ}$ to $110^{\circ}$. Both generations of dykes are continuous for several tens of kilometres and mainly between 10 and 50 metres in width.

Most of the E-W dykes appear to be ordinary ophitictextured dolerites similar to the MD dykes of southern West Greenland (Hall et al., this volume - Basic dykes), but some are noritic in composition, similar to dykes common in the Sukkertoppen region, West Greenland, and to some of the Scourie dykes of Scotland (Hall et al., 1987b). A few low angle cross-cutting relationships demonstrate that the noritic dykes are older than the dolerites.

Field relationships suggest that the E-W dykes were emplaced into a normal tensional regime. They are generally straight-sided and show many igneous emplacement structures (figs 2, 3). The dykes cut each other locally at a low angle suggesting the presence of more than one generation of dykes, but many apparent intersections have no chilled margins and are inter- 


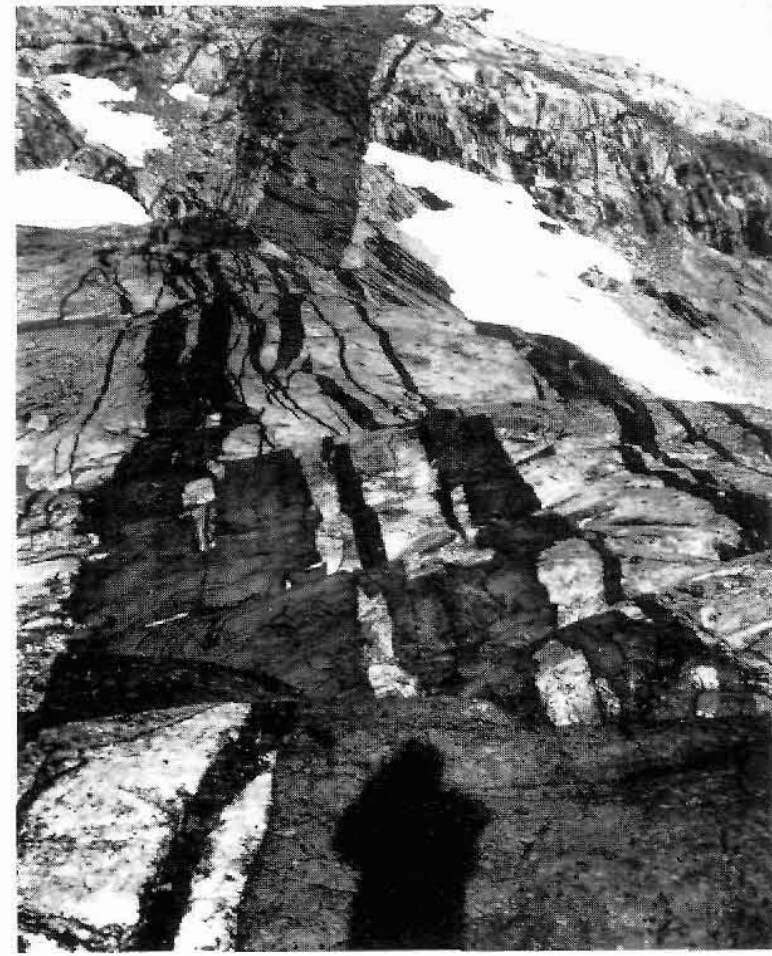

Fig. 3. Primary igneous emplacement features in an E-W dyke in Archaean gneisses south of the mobile belt. Note the chilled margins to some of the thinner dykes. Qataq, western Gyldenløve Fjord.

preted as dyke bifurcations. En echelon and en bayonet relations are also common and swarms of narrow, closely spaced, parallel dykes occur in some instances. Some dykes have irregular outlines which thin and thicken over very short distances, while others have numerous apophyses (fig. 3) resembling the shape of some of the moderately deformed basic Charcot Fjelde dykes in the northern boundary zone of the Proterozoic mobile belt (Dawes et al., this volume - Northern boundary).

The dykes in the southern area are variably altered, most being only deuterically altered and some retaining fresh igneous mineralogy (Hall et al,, this volume Basic dykes). The lack of any deformational fabric within the dykes indicates that they were not affected by the nearby Proterozoic deformation of the northern area. A few of the wider dykes $(>50 \mathrm{~m}$ ) have central felsic zones which possess irregularly distributed, rounded, epidote-rich concentrations up to $50 \mathrm{~cm}$ across.

The dykes on Zebrafjeld have been reported to consist of garnet-bearing amphibolites (Andrews et al., 1973, plate 2a; Bridgwater, 1976, fig. 92) indicating amphibolite facies metamorphism. While some of the dykes are in part epidotized and amphibolitized, they all retain a clear relict doleritic texture and composition and show no evidence of such high-grade metamorphism.

\section{The southern border zone of the mobile belt}

The location and age of the southern boundary of the mobile belt is inconsistent in earlier reports. On the generalised map of Bridgwater \& Myers (1979, fig. 1), reproduced by Myers $(1984,1987)$, the boundary is depicted as an E-W trending Nag. 2 shear zone at the southern end of Jens Munk $\varnothing$. However, on photographs of the same boundary, the shear zone was placed on Sorte Rytter Fjelde, some $15 \mathrm{~km}$ farther to the north (Myers, 1984, fig. 9a; 1987, fig. 4a) and interpreted as a Nag. 1 structure. Additionally, the sense of displacement on the bounding shears has been described as dextral, whereas our observations indicate that most

Fig. 4. Swarm of cross-cutting E-W trending basic dykes in the boundary zone. The dykes have been weakly folded and sheared, but are still clearly discordant to the fabric of the gneisses. They are roughly parallel with the E-W trending Proterozoic shear movements. Height of cliff face about $150 \mathrm{~m}$; unnamed nunatak south of Hørring Nunatak.

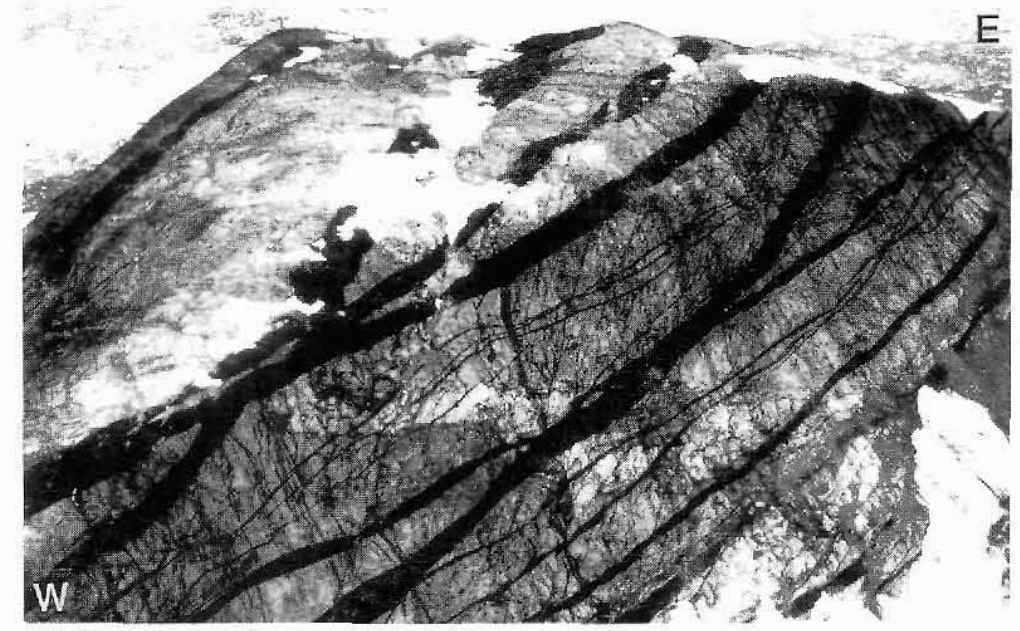




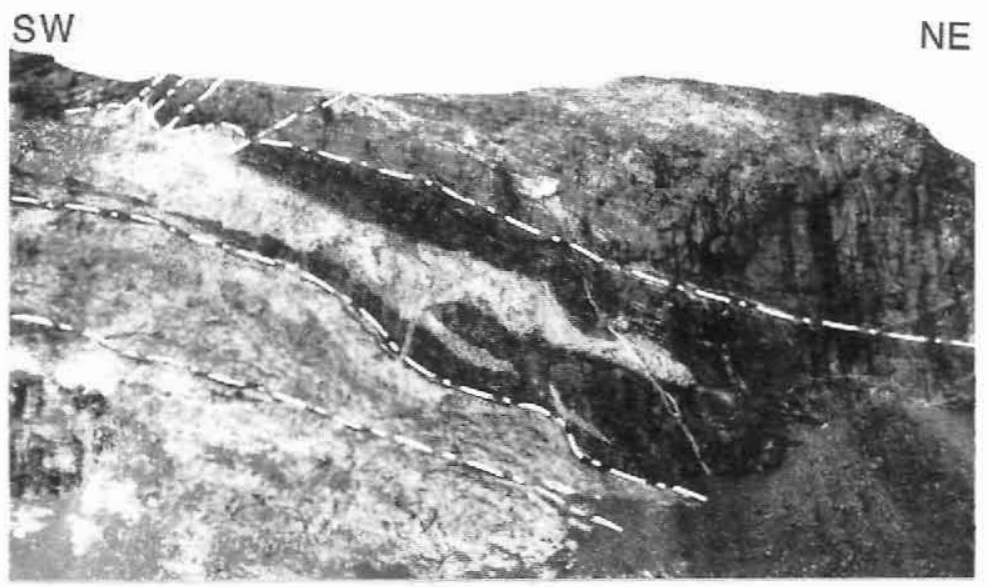

Fig. 5. Multiple. gently north-dipping thrust, with Archaean granulite facies gneisses (dark) overlying grey amphibolite facies gneisses (pale). Height of cliff about $400 \mathrm{~m}$; NE Sadelfjeldet, Umivik region.

shears in the boundary zone occurred with sinistral movements.

The southern boundary has been described as an abrupt transition along which, and to the north of it, the basic dykes were brought into parallelism with a rotated gneiss fabric (Bridgwater \& Myers, 1979; Myers, 1984. 1987). We agree with such a deformation of the dykes and gneisses (fig. 4), but we were not able to distinguish a sharp tectonic boundary between the two areas. Instead, we mapped an E-W trending boundary zone of progressive shear deformation, about $25 \mathrm{~km}$ wide, forming a gradual transition from the unmodified Archaean gneiss complex of the southern area to the strongly deformed gneisses and dykes of the northern area (fig. 1). Inside this zone, discrete northerly dipping shear and thrust zones show a general sense of displacement compatible with a sinistral southward move- ment of the Proterozoic reworked rocks over the Archacan gneisses, similar to the situation observed in the northern boundary zone of the mobile belt (Dawes et al., this volume - Northern boundary).

The southernmost major shear zones of the boundary zone occur in the northern Umivik region and also generally show a sinistral sence of displacement. A major thrust, dipping gently to the north, occurs on Sadelfjeldet and has transported brown granulite facies gneisses above grey amphibolite facies gneisses (fig. 5). The grey gneisses of the footwall belong to the Archaean gneiss complex of the southern region. The brown gneisses of the hanging wall probably represent a slice of weakly reworked Archaean granulite facies rocks of the northern area, thrust south over the grey Archaean gneisses. This occurrence suggests that granulite facies rocks may occur farther to the north-west

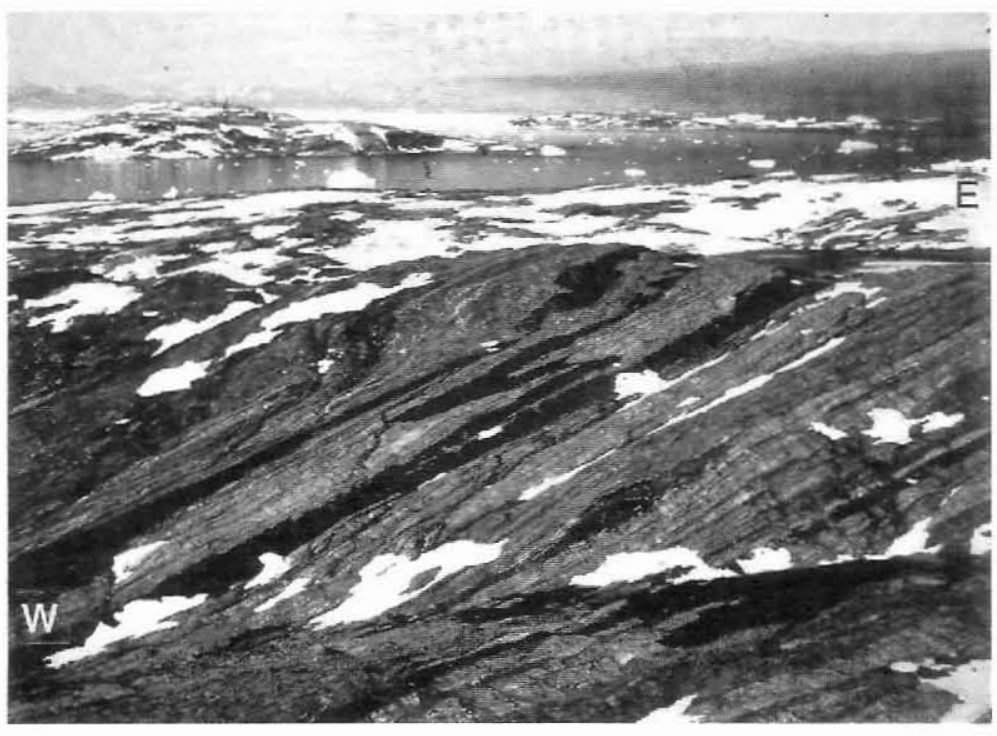

Fig. 6. Two orientations of deformed and metamorphosed basic dykes brought almost into parallelism by deformation within the Proterozoic mobile belt. Central Hornemann $\varnothing$. 
Fig. 7. Strongly deformed amphibolite dykes forming asymmetric folds in a zone of intense Proterozoic deformation on the limb of a large recumbent isoclinal fold. Fold closure situated to the left (west) of this locality. Note the progressive boudinage from west to east of the basic dyke in the centre. Height of cliff above water level about $70 \mathrm{~m}$; Pamiagtik, Køge Bugt.

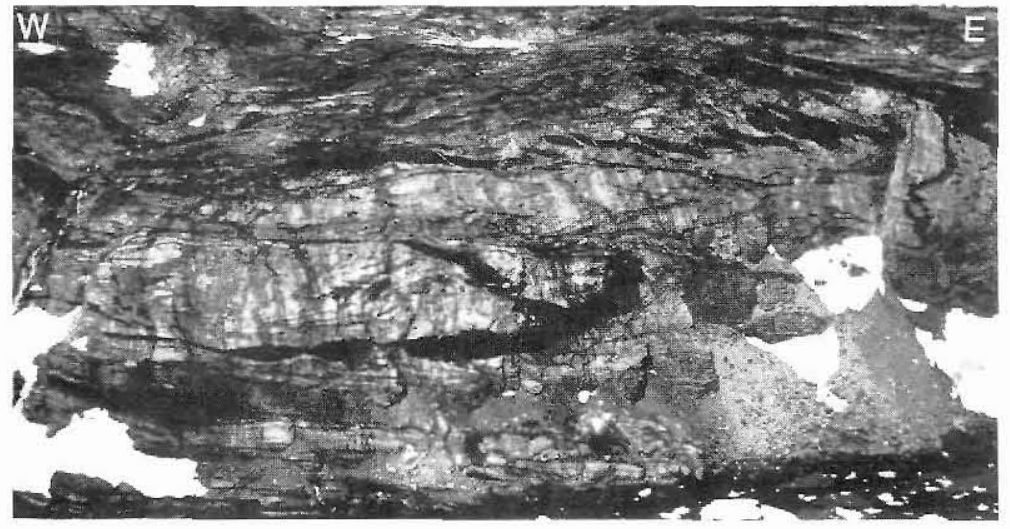

under the Inland Ice. The thrust at NE Sadelfjeldet has several similarities with a granulite-amphibolite facies gneiss thrust in the Niflheim region (Escher \& Hall, this volume), situated at the very southern limit of the northern boundary zone of the mobile belt.

\section{The Proterozoic mobile belt}

Within the northern area, the gneisses have been refolded, sheared by a dense series of roughly $\mathrm{E}-\mathrm{W}$ trending shear zones and re-foliated with a well-developed mylonitic texture in many places. The Proterozoic basic dykes have also been strongly deformed, and occur as folded, sheared and boundinaged amphibolite layers with orientations sub-parallel to the new gneiss foliation (figs 6,7 ). Our observations indicate that the Proterozoic deformation at the exposed crustal level has taken place at amphibolite facies, and not at greenschist facies as suggested by Bridgwater \& Myers (1979) and Myers (1984, 1987).

Occasionally tectonic augen of nebulitic gneiss with variably preserved Archaean structures and a low degree of Proterozoic deformation are preserved within the mylonitic gneisses (fig. 8). These augen vary in size from a few metres in diameter up to bodies of approximately 200 by $300 \mathrm{~m}$, and in general they become progressively smaller and less common northwards. The most northerly of these augen are found near Isertoy (Friend \& Nutman, this volume). The augen in the area between Isertoq and Køge Bugt mainly consist of grey amphibolite facies gneisses which do not resemble retrogressed granulite facies gneisses, while the augen to the south between Køge Bugt and the southern boundary zone mainly consist of variably retrogressed purplish and brownish orthopyroxene-bearing granulite facies gneisses. Dykes inside the augen have relict ophitic textures and preserve discordant intrusive relationships but have moderately foliated amphibolitic margins, clearly indicating that some Proterozoic modification took place inside the augen.

Considering that the structure of the mobile belt essentially comprises a series of shear zones, thrust slices and nappes (e.g. Chadwick et al., this volume) it is likely that amphibolite facies and granulite facies crustal segments were intercalated during the Proterozoic deformation of this region, but apparently with a predominance of amphibolite facies segments, since amphibolite facies augen are the most commonly observed type. The augen are surrounded by amphibolite facies gneisses with an intense, commonly mylonitic, $L S$ fabric which virtually obliterates the earlier Archaean structures. On Søren Nordbye Øer and at several localities on Jens Munk $\varnothing$, an intense mineral rodding of the gneisses is dominant and is related to the position of these gneisses in the noses of tight to isoclinal folds. This strong $L$ fabric and associated hinge lines of the folds generally plunge gently to the north-west, with a few plunging gently south-east (fig. 9a). Thus, despite the concentration of Proterozoic deformation into E-W

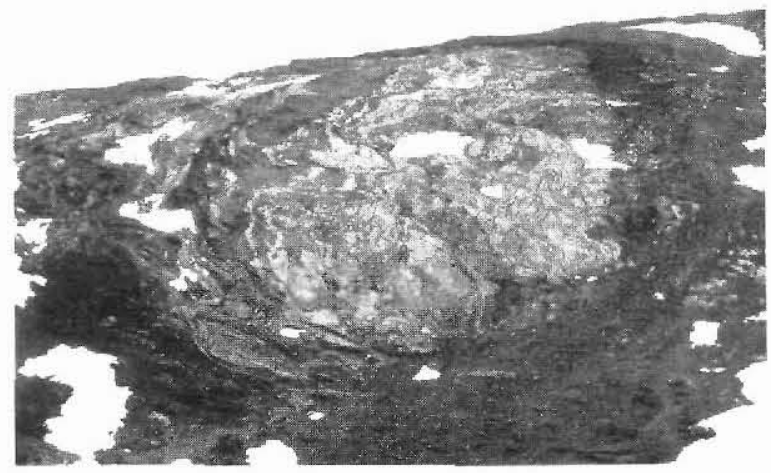

Fig. 8. Augen of low Proterozoic deformation with pale-purplish weathering nebulitic Archaean gneisses, surrounded by strongly reworked (Proterozoic) grey gneisses. Diameter of augen about $200 \mathrm{~m}$; north-west coast of Køge Bugt. 
A

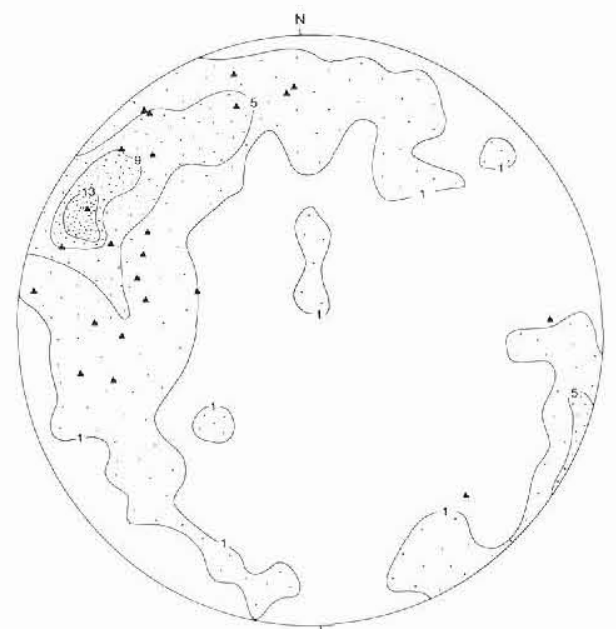

$\mathrm{B}$

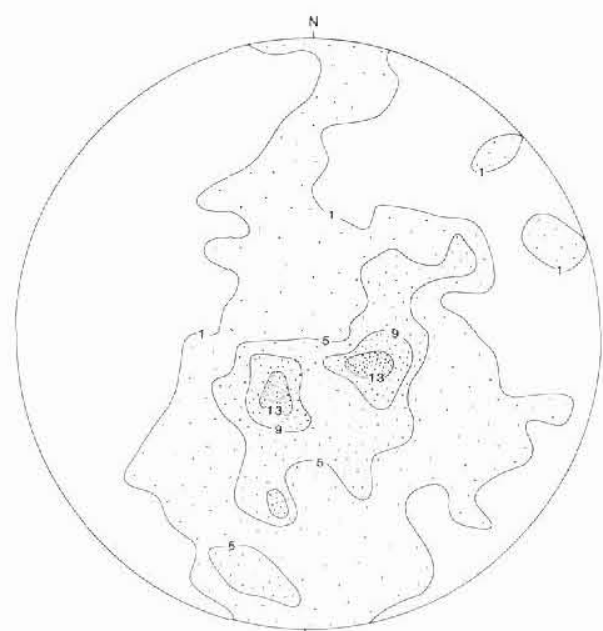

Fig. 9. Stereographic projections of structural data for the gneisses of the Umivik-Isertoq region; (A) 136 mineral lineations and 23 fold hinges (triangles); (B) poles to 186 foliation surfaces.

trending structures, the foliation throughout the area is variable and reflects all stages of modification and rotation of the Archaean fabric into a new orientation imposed by the Proterozoic deformation (fig. 9b).

Our observations indicate that the E-W dykes were emplaced prior to the main phase of Proterozoic deformation. It is, however, not clear if some of the dykes were emplaced into pre-existing Proterozoic or older shear zones which were subsequently reactivated; such emplacement conditions are common for the Charcot Fjelde dykes in the northern boundary zone of the mobile belt (Dawes et al., this volume - Northern boundary). The sheared and foliated dykes of the northern area appear to form a common swarm, although occasional examples of cross-cutting relationships do occur within the swarm (fig. 6).

Numerous M-shaped, small scale, folded basic dykes occur on the Refsnæs peninsula (fig. 10). These are situated in the closure of a large-scale gently north dipping recumbent fold. At this locality deformation has been of moderate intensity as the amphibolites form more or less continuous dyke shapes. About $1 \mathrm{~km}$ north of the locality shown in fig. 10, north of the fold core, in the $\mathrm{N}-\mathrm{S}$ trending fjord section through the limb zone of this structure, the basic dykes are extremely altered, boudinaged, and often tightly folded; parts of the dykes are typically only preserved as discrete amphibolite pods in mylonitic grey gneisses. Our interpretation that

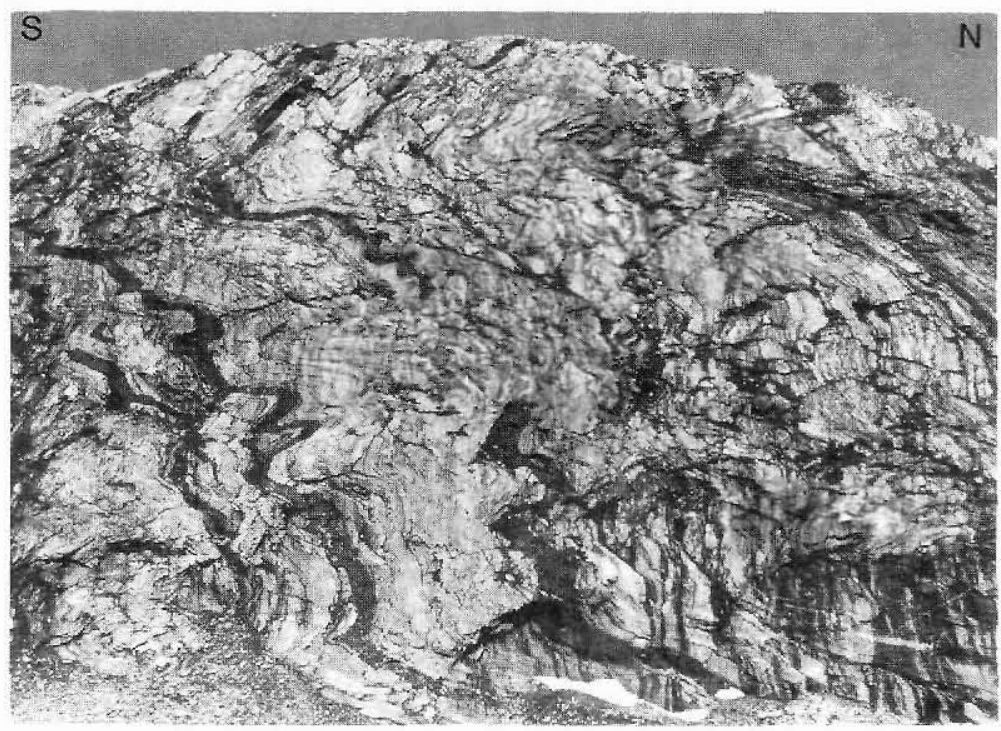

Fig. 10. M-shape folded and boudinaged basic dykes in the nose of a large-scale, flatlying fold at Refsnæs, $16 \mathrm{~km}$ west of Isertoq. Height of ridge about $400 \mathrm{~m}$. 
Refsnæs represents part of a major, relatively lowstrain, flat-lying fold core is very different from the interpretation of Bridgwater \& Myers (1979) and Myers (1987) in which this locality was depicted as part of a zone of extreme deformation representing the most northerly 'Nag. 2' shear zone of the region. A similar situation occurs along the north side of Køge Bugt (fig. 7), where small-scale flat-lying folds commonly display severely sheared limbs, but have relatively well preserved cores within predominantly mylonitic gneisses. Similarly, in the area immediately to the north of Isertoq, amphibolite dykes are folded around tight nappe structures which show a southerly sense of transport (Chadwick \& Vasudev; Friend \& Nutman, both this volume).

Where the dykes are boudinaged, the boudins frequently have brown weathering cores which preserve either the original igneous texture or an early metamorphic texture with garnet formed in reaction between pyroxene and plagioclase. The dyke boudin margins consist of intensely foliated and lineated fine-grained garnet amphibolite.

Our field observations also indicate that the majority of the Proterozoic dykes in the northern area was intruded before the main deformation of the mobile belt. The shapes of the dykes as seen today are predominantly the result of inhomogeneous deformation of regular, parallel-sided dykes; they do not reflect syntectonic emplacement as has been proposed previously (Bridgwater, 1976; Bridgwater \& Myers, 1979; Myers, 1984, 1987).

The structure of the northern area has previously been depicted as a series of discrete shear zones (Bridgwater \& Myers, 1979). However, while major shear belts of considerable tectonic intensity are present, this interpretation is over-simplified, as parts of the gneisses have also been folded into large nappe structures with severely sheared limbs. This is evident from the wide range of foliation directions recorded throughout the region (fig. 9b). We emphasize that the foliation data presented in fig. $9 \mathrm{~b}$ are poorly constrained and include both Archaean and Proterozoic elements. However, the predominant foliation within the southern part of the mobile belt dips gently north-westwards and coincides with the main rodding lineation azimuth (fig. 9a), and reflects the dominance of the Proterozoic deformation. All of these data corroborate a general transport direction of the reworked rocks upwards to the south-southeast, the same as observed in the northern boundary zone of the mobile belt (Dawes et al., this volume Northern boundary). Fold axes are also variable in orientation but broadly correspond to that of the main stretching lineation direction, suggesting a substantial transcurrent component of Proterozoic deformation.

\section{Late and post-Proterozoic rocks}

Large intrusions of medium- to coarse-grained dioritic to granitic rocks occur in the vicinity of Isertoq. They cut the fabric of the surrounding gneisses, demonstrating that the intrusions post-date the Proterozoic deformation of the northern area. The intrusive rocks are generally only weakly foliated. Discrete, irregularly oriented c. $2 \mathrm{~m}$ thick diorite dykes, related to the granitic intrusions, intrude the gneisses north of Refsnæs. The larger intrusions have a greenchist facies metamorphic aureole in which garnetiferous gneisses are retrogressed to chloritic rocks. Isotope data indicate that these rocks were emplaced at $c .1570 \mathrm{Ma}$ (Pedersen \& Bridgwater, 1979; Taylor et al., 1984).

An approximately $4 \mathrm{~m}$ thick and $300 \mathrm{~m}$ long NW trending plumasite dyke, dipping gently to the northeast, was examined in western Zebrafjeld. This dyke was first observed by D. Bridgwater in 1968 (personal communication, 1986). It is medium-grained and has a pale yellow-green and grey epidote-bearing groundmass containing euhedral, pinkish corundum crystals up to 10 $\mathrm{cm}$ long and $1 \mathrm{~cm}$ wide which are variably altered to margarite pseudomorphs. The surrounding gneisses are epidotized for a distance of 2-3 $\mathrm{m}$ away from the margins of the dyke, with narrow epidote veins extending for many metres further into the gneisses indicating that the dyke was associated with significant hydrothermal activity. The age of this dyke is poorly constrained, although it does not have a tectonic fabric and is younger than the undeformed Proterozoic dykes through which it cuts. No relationship with any shear zone was found.

Late shears and faults cut through the gneiss complex causing irregular chloritization, epidotization and reddening of feldspars. Bridgwater \& Myers (1979) suggested that at least some of this retrogression was relatively early and associated with the development of the mobile belt. However, close investigation shows that apart from the hydrothermal activity associated with the plumasite dyke, similar epidotization effects are commonly related to the emplacement of the $\mathrm{N}-\mathrm{S}$ trending basic dykes of supposed Tertiary age. Distinct bleached or reddened zones up to $20 \mathrm{~m}$ wide have been developed in the gneisses along both contacts of many of these dykes. Additionally, some of the dykes in these altered zones have themselves been extensively hydrothermally altered. Thus, much of the low-grade alteration appears to be much later than previously pro- 
posed, and does not reflect a Proterozoic high level deformation (Myers, 1987).

\section{Conclusions}

The unmodified Archaean gneisses in the southern part of our study area sharply contrast in tectonic style with the rocks within the mobile belt. The southern boundary of the mobile belt is traceable across the northern Umîvik area as a roughly $\mathrm{E}-\mathrm{W}$ trending zone of series of discrete shear and thrust zones, some $25 \mathrm{~km}$ wide. The Archaean gneisses south of the boundary zone and the Proterozoic reworked gneisses of the mobile belt to the north originally contained both amphibolite facies and granulite facies segments. Granulite facies gneisses are locally thrust above amphibolite facies gneisses. Evidence from augen of low deformation within the mobile belt suggests that granulite facies rocks were once much more extensive. This is comparable to the metamorphic and tectonic development of the northern boundary zone of the mobile belt (Dawes $e t$ al., this volume - Northern boundary).

The intrusion of the $\mathrm{E}-\mathrm{W}$ trending basic dykes north of the boundary zone was not a syn-tectonic event, as postulated by Bridgwater \& Myers (1979). Instead the highly irregular shapes displayed by the dykes simply reflect their response to the inhomogeneous deformation that occurred after the intrusion of the dykes during the Proterozoic deformation. A complete sequence of progressive dyke deformation has been observed across the boundary zone between Umîvik and Jens Munk $\emptyset$. Similarly, the increase in the number of basic dykes from south to north across the boundary zone is not an indication that the dykes were intruded during the Proterozoic deformation of the belt (cf. Bridgwater \& Myers, 1979), but rather is a consequence of post-emplacement deformation, mainly by simple shear which resulted in a general thinning and a more closely spaced distribution of the dykes.

Our investigation also shows that the use of the Nag. 1 and Nag. 2 deformational events, transposed from West Greenland by Bridgwater \& Myers (1979), is not justified; in the case of West Greenland some shear zones previously referred to as 'Nag. 1' have turned out to be Archaean and not Proterozoic (Kalsbeek, 1979), whereas the majority of the new fabrics and structures described here clearly post-date the emplacement of the E-W dykes and are therefore Proterozoic in age. 